\title{
Barium Activates Rat Cerebellar Nitric Oxide Synthase
}

\author{
Jun Yamazaki ${ }^{\sharp}$, Tetsuro Urushidani and Taku Nagao \\ Department of Toxicology and Pharmacology, Faculty of Pharmaceutical Sciences, University of Tokyo, Tokyo 113, Japan
}

Received January 5, 1996 Accepted February 17, 1996

\begin{abstract}
Ba}^{2+}$ is known to pass through $N$-methyl-D-aspartate receptor channels and cause an increase in cGMP levels in rat cerebella. In the present study, we compared the activation of rat cerebellar nitric oxide synthase (NOS) by $\mathrm{Ba}^{2+}$ with that produced by $\mathrm{Ca}^{2+}$. Both cations stimulated L-citrulline formation in the presence of calmodulin in identical fractions eluted from an anion exchange column with a salt gradient. $\mathrm{EC}_{50}$ values for $\mathrm{Ca}^{2+}$ and $\mathrm{Ba}^{2+}$ were $200 \mathrm{nM}$ and $50 \mu \mathrm{M}$, respectively. The $\mathrm{IC}_{50}$ of $N^{G}$ monomethyl-L-arginine was the same $(200 \mathrm{nM})$. These indicate a possible action of $\mathrm{Ba}^{2+}$ on NOS through the calmodulin-dependent pathway.
\end{abstract}

Keywords: Barium, Nitric oxide synthase, Calmodulin

Nitric oxide (NO) is thought to be a messenger molecule in cerebella, and the characteristics of cerebellar nitric oxide synthase (NOS) have been well-defined; activation of NOS is absolutely dependent on $\mathrm{Ca}^{2+}$ and calmodulin $(1,2)$, and this underlies the mechanism of the physiological response to $N$-methyl-D-arpartate (NMDA) in cerebella. Glutamate and NMDA release endotheliumderived relaxing factor (EDRF)-like messengers from cerebellar cells (3) increase cGMP levels (4-6) and enhance the conversion of L-arginine to L-citrulline $(4,6)$ through NMDA-receptor activation in cerebellar cells. This messenger is produced in a $\mathrm{Ca}^{2+}$-dependent manner $(3,7)$.

Another alkaline earth cation, $\mathrm{Ba}^{2+}$, causes a $\mathrm{Ca}^{2+}$. mimetic action in NO-generating tissue. Recently, we reported that $\mathrm{Ba}^{2+}$ as well as $\mathrm{Ca}^{2+}$ relaxes canine coronary artery and increases cGMP levels (8). Electrophysiological studies with central nervous cells have demonstrated that $\mathrm{Ba}^{2+}$ can substitute for $\mathrm{Ca}^{2+}$ and pass through NMDA-receptor channels (9). Interestingly, Carter et al. (10) have shown that the NMDA-induced increase in cGMP in the cerebellum is not blocked by $\mathrm{Ba}^{2-}$ and persists when $\mathrm{Ba}^{2+}$ is substituted for $\mathrm{Ca}^{2+}$. This raises the possibility that $\mathrm{Ba}^{2+}$ activates cerebellar NOS. To explain this phenomenon, direct evidence for $\mathrm{Ba}^{2+}$ induced activation of NOS is needed, and also, it should be determined if calmodulin is required. Therefore, the present study was undertaken to investigate whether

\footnotetext{
${ }^{\dot{P}}$ Present address: Department of Physiology, University of Nevada School of Medicine, Reno, Nevada 89557-0046, U.S.A.
}

$\mathrm{Ba}^{2+}$ can directly activate NOS in rat cerebella.

Cerebella of twelve male Wistar rats $(150-200 \mathrm{~g}$, Charles River Japan, Atsugi) were homogenized in $30 \mathrm{ml}$ ice-cold buffer containing $50 \mathrm{mM}$ Tris- $\mathrm{HCl}$ (pH 7.4), $1 \mathrm{mM}$ ethylenediaminetetraacetic acid (EDTA), $1 \mathrm{mM}$ dithiothreitol, $100 \mathrm{mg} / \mathrm{l}$ phenylmethylsulfonyl fluoride, $10 \mathrm{mg} / 1$ leupeptin and $10 \mathrm{mg} / 1$ pepstatin A (Sigma, St. Louis, MO, USA). The homogenate was centrifuged at $20,000 \times \mathrm{g}$ for $15 \mathrm{~min}$ at $4^{\circ} \mathrm{C}$. The supernatant was loaded onto a $20-\mathrm{ml}$ column of DEAE Sepharose Fast Flow (Pharmacia Biotech, Uppsala, Sweden). After the column had been washed with $50 \mathrm{ml}$ buffer, a $100-\mathrm{ml}$ linear gradient $(0-300 \mathrm{mM}) \mathrm{NaCl}$ was applied at a speed of $1.5 \mathrm{ml} / \mathrm{min}$. The eluate fraction was collected and stored at $-80^{\circ} \mathrm{C}$ until use.

NOS activity was measured by monitoring the conversion of L-arginine to L-citrulline. Unless otherwise indicated, the assay mixture contained $50 \mathrm{mM}$ Hepes $(\mathrm{pH}$ 7.4), $1 \mathrm{mM}$ dithiothreitol, $1 \mathrm{mM} \mathrm{NADPH}, 10 \mu \mathrm{M}(6 R)$ 5,6,7,8-tetrahydro-L-biopterin, $100 \mathrm{nM}$ calmodulin (from bovine brain, Sigma) and $1 \mathrm{mM}$ EDTA. $\mathrm{Ca}^{2-} / \mathrm{Ba}^{2+}$. EDTA buffer was prepared according to the previously described method for computing metal ion concentrations (11). One hundred microliters of the assay mixture, $25 \mu 1100 \mathrm{nM}\left[{ }^{3} \mathrm{H}\right] \mathrm{L}$-arginine (NEN, Wilmington, DE, USA) and $25 \mu 1$ enzyme protein were mixed and incubated for $6 \mathrm{~min}$ at $37^{\circ} \mathrm{C}$. The enzyme reaction was terminated with a stop buffer containing $2 \mathrm{ml} 20 \mathrm{mM}$ Hepes ( $\mathrm{pH} 5.5$ ) and $6 \mathrm{mM}$ EDTA. The reaction mixture was applied to a $1 \mathrm{ml}$ column of Dowex AG50WX-8 $\left(\mathrm{Na}^{+}\right.$form; BioRad, 
a

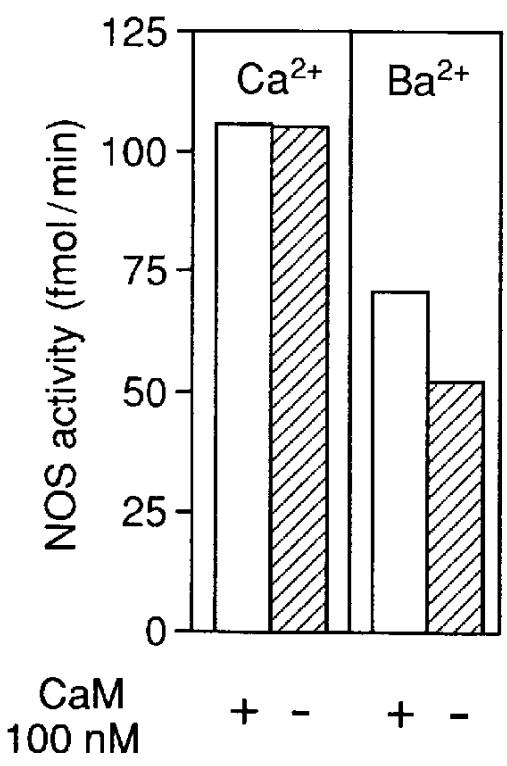

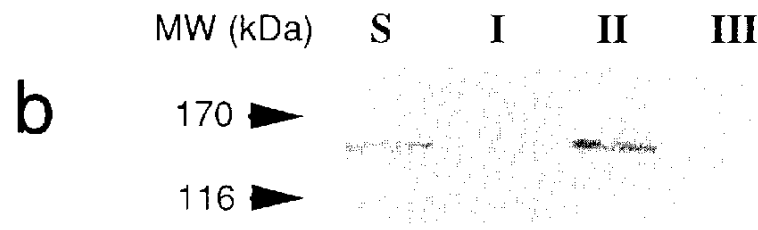

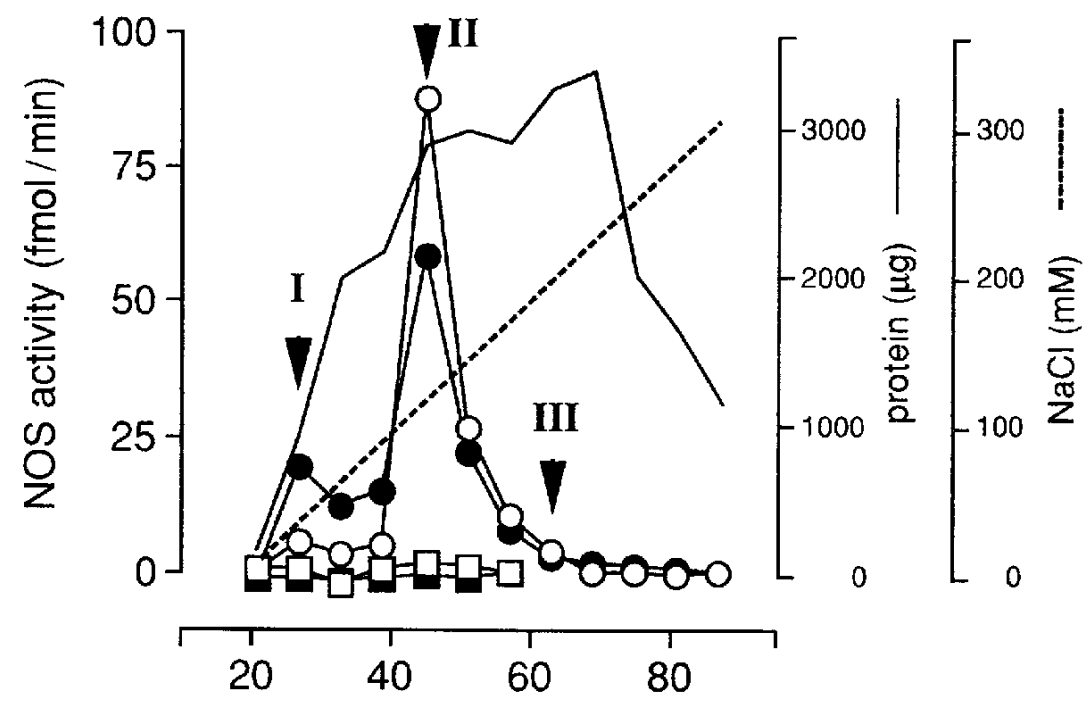

Fraction (ml)

Fig. 1. Partial purification of cerebellar NOS on DEAE sepharose. NOS activity was measured in the presence of $\mathrm{Ca}^{2+}$ and $\mathrm{Ba}^{2+}$ by monitoring the conversion of $100 \mathrm{nM}\left[{ }^{3} \mathrm{H}\right] \mathrm{L}$-arginine $(2.5 \mathrm{pmol})$ to $\left[{ }^{3} \mathrm{H}\right] \mathrm{L}$-citrulline in the $20,000 \times \mathrm{g}$ supernatant $(57.3$ $\mu \mathrm{g}$ ) (a) and DEAE eluate fractions (b). Data are from a representative purification. $\mathrm{O}, \mathrm{Ca}^{2+}(300 \mathrm{nM})$ plus calmodulin (CaM) $(100 \mathrm{nM}) ; 0, \mathrm{Ba}^{2+}(100 \mu \mathrm{M})$ plus CaM $(100 \mathrm{nM}) ; \square, \mathrm{Ca}^{2+}(300 \mathrm{nM}), \mathrm{CaM}-$ free; $\square, \mathrm{Ba}^{2+}(100 \mu \mathrm{M})$, CaM-free. Western blot analysis is shown for the supernatant (S) and DEAE effluent (I, Il and III) samples using rabbit anti-brain NOS antibody.

Hercules, CA, USA) before $\left[{ }^{3} \mathrm{H}\right]$ citrulline (NEN) was eluted with $4 \mathrm{ml}$ water. The eluate was collected and counted by a liquid scintillation spectrometer (Beckman, Palo Alto, CA, USA) after addition of a scintillation cocktail (Aquasol-2, NEN). The protein content was measured by the Bio-Rad assay with bovine serum albumin as the standard. Results are expressed as means \pm S.E.M.

In crude rat cerebellar supernatant, $\mathrm{Ca}^{2+}(300 \mathrm{nM})$ and $\mathrm{Ba}^{2+}(100 \mu \mathrm{M})$ increased $\left[{ }^{3} \mathrm{H}\right]$ citrulline formation (Fig. 1a). The activity of $\mathrm{Ba}^{2+}$ was approximately $65 \%$ that of $\mathrm{Ca}^{2+}$. The crude cerebellum supernatant was loaded onto a DEAE-Sephalose column. When the column was washed with buffer, the effuent showed no L-citrulline forming activity during concomitant incubation with $\mathrm{Ca}^{2+}$ or $\mathrm{Ba}^{2+}$. Thus, the enzyme appeared to have adhered to the DEAE column (data not shown). However, the eluate obtained by $\mathrm{NaCl}$ gradient $(0-300 \mathrm{mM})$ elution could catalyze $\mathrm{Ca}^{2+}$ - and $\mathrm{Ba}^{2+}$-induced citrulline formation in the presence of calmodulin (Fig. 1b). Both $\mathrm{Ca}^{2-}$. and $\mathrm{Ba}^{2+}$-induced activities eluted in the same fraction, which contained approximately $120 \mathrm{mM} \mathrm{NaCl}$. The peak activity of $\mathrm{Ba}^{2+}$ was approximately $65 \%$ that of $\mathrm{Ca}^{2+}$ When calmodulin was omitted from the assay mixture, the activity in the DEAE eluate was lost (Fig. 1b), whereas activity still remained in the crude fraction because of the presence of endogenous calmodulin (Fig. 1a).

Samples of the crude supernatant fraction and fractions from the DEAE column were denatured with sodium dodecyl sulfate, electrophoresed on a $7.5 \%$ polyacrylamide gel, transferred to a polyvinylidene diffuoride membrane and immunoblotted with polyclonal (rabbit) anti-brain NOS antibody (Affinity BioReagents, Neshanioc Station, NJ, USA) and HRP-conjugated donkey anti-rabbit IgG (Amersham, Arlington Heights, IL, USA). A single band (approximately $160 \mathrm{kDa}$ ) was recognized in the crude fraction (S) and the peak fraction (II) of the DEAE eluate, but not in the fractions that exhibited little L-citrulline formation (Fig. 1b). These findings indicate that the $\mathrm{Ba}^{2+}$ and $\mathrm{Ca}^{2+}$ can enhance the formation of $\mathrm{L}$-citrulline from L-arginine using an identical NOS.

$\mathrm{Ca}^{2+}-$ and $\mathrm{Ba}^{2+}$-induced L-citrulline formation (NOS 
a

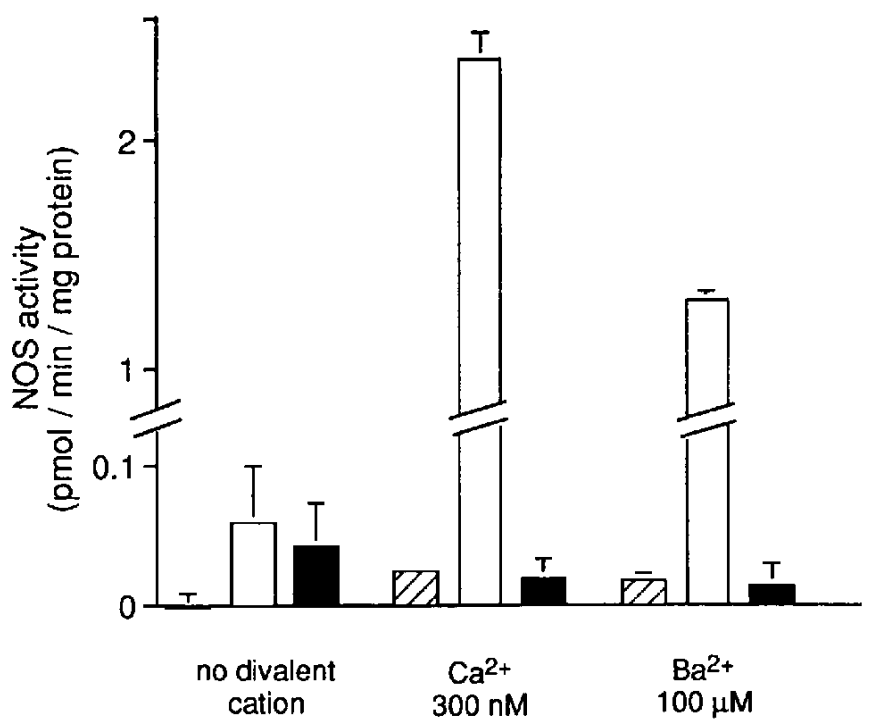

b

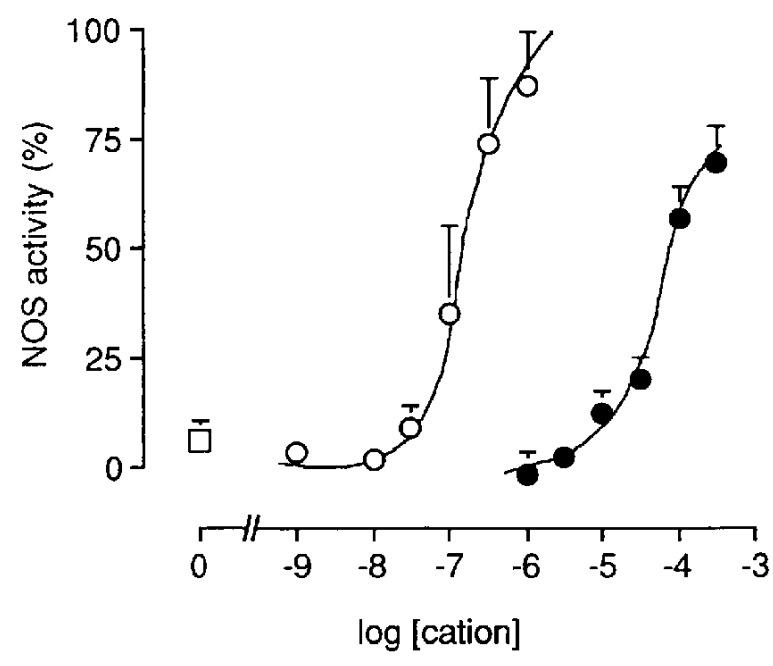

Fig. 2. $\mathrm{Ca}^{2-}, \mathrm{Ba}^{2+} /$ calmodulin $(\mathrm{CaM})$ dependency of partially purified cerebellar NOS. a: CaM dependency of the NOS activation by $\mathrm{Ca}^{2} \cdot(300 \mathrm{nM})$ and $\mathrm{Ba}^{2 \prime}(100 \mu \mathrm{M})$. Data are the means of three separate experiments with S.E.M. $\forall$, CaM-free; $\square$, $\mathrm{CaM}(100 \mathrm{nM}) ; \mathbf{D}, \mathrm{CaM}(100 \mathrm{nM})$ plus calmidazolium $(100 \mathrm{nM})$. b: Concentration-dependency on $\mathrm{Ca}^{2+} / \mathrm{Ba}^{2+}$. NOS activity was assayed with the DEAE eluate fraction $(17.9 \pm 2.0 \mu \mathrm{g})$ containing the major activity peak and is expressed as a percentage of the maximal activity stimulated by $\mathrm{Ca}^{2+}(300 \mathrm{nM}$ or $1 \mu \mathrm{M})$. CaM $(100 \mathrm{nM})$ was present. Data are the means of four separate experiments with S.E.M. O, $\mathrm{Ca}^{2+} ; \mathrm{O}, \mathrm{Ba}^{2+} ;[$.$] , EDTA only.$

activity) in the peak DEAE effluent fraction was dependent on calmodulin, and it was completely inhibited by the calmodulin inhibitor calmidazolium (100 nM, Sigma) (Fig. 2a). $\mathrm{Ca}^{2+}$ and $\mathrm{Ba}^{2+}$ increased NOS activity in a concentration-dependent manner (Fig. 2b). The $\mathrm{EC}_{50}$ value for $\mathrm{Ca}^{2+}$ was $200 \mathrm{nM}$, similar to those obtained in previous studies $(1,2)$. The $\mathrm{EC}_{50}$ for $\mathrm{Ba}^{2-}$ was $50 \mu \mathrm{M}$, which is 250 times higher than that for $\mathrm{Ca}^{2+}$. The maximal activity of $\mathrm{Ba}^{2+}$ was approximately $70 \%$ that of $\mathrm{Ca}^{2+}$. The NOS inhibitor $N^{G}$-monomethyl-L-arginine (LNMMA; donated by Tanabe Seiyaku, Toda) inhibited the NOS-activating effect of both cations in a concentrationdependent manner in four separate experiments. More than $3 \mu \mathrm{M}$ L-NMMA completely abolished the activity of both $\mathrm{Ca}^{2+}(300 \mathrm{nM})$ and $\mathrm{Ba}^{2+}(100 \mu \mathrm{M})$. The $\mathrm{IC}_{50}(200$ $\mathrm{nM}$ ) of L-NMMA for $\mathrm{Ba}^{2+}$ was the same as that for $\mathrm{Ca}^{2+}$.

Stimulation of NMDA receptors has been shown to increase cGMP levels in the presence of $\mathrm{Ba}^{2+}$ as a replacement for $\mathrm{Ca}^{2-}(10)$. This raises the possibility that $\mathrm{Ba}^{2+}$ may enter into the cerebellar cells and activate NOS, leading to an increase in cGMP levels. The present study aimed to provide substantial evidence for $\mathrm{Ba}^{2+}$-induced activation of NOS. To this end, we used the conversion of $\left[{ }^{3} \mathrm{H}\right] \mathrm{L}$-arginine to $\left[{ }^{3} \mathrm{H}\right] \mathrm{L}$-citrulline as a measure of the NOS activity in rat cerebella. The present crude and partially purified NOS preparation requires the addition of $\mathrm{Ca}^{2+}$ to the reaction mixture for activity. This agrees well with the results of previous studies using constitutive NOS from the cerebellum $(1,2)$. The requirement of $\mathrm{Ca}^{2+}$ for NOS activation in the crude homogenate indicates that EDTA effectively chelates endogeneous $\mathrm{Ca}^{2+}$ so that free $\mathrm{Ca}^{2+}$ present cannot increase NOS activity.

$\mathrm{Ba}^{2+}$ also increased NOS activity in the crude preparation. However, since much higher concentrations of $\mathrm{Ba}^{2+}$ are needed (see below), care should be taken to avoid the possibility of contamination by free $\mathrm{Ca}^{2+}$ since the $\mathrm{Ca}^{2+}$ bound to the chelator may be displaced by $\mathrm{Ba}^{2+}$. In the partially purified NOS preparation, which excludes any interference by endogenous divalent cations, $\mathrm{Ba}^{2+}$ as well as $\mathrm{Ca}^{2+}$ increased $\mathrm{L}$-citrulline formation in a concentration-dependent manner. The elution pattern of $\mathrm{Ba}^{2+}$-induced $\mathrm{L}$-citrulline formation was, however, similar to that of $\mathrm{Ca}^{2+}$-induced formation. Immunoblotting analysis showed that the fraction exhibiting the highest activity with both cations included neuronal constitutive NOS, suggesting that $\mathrm{L}$-citrulline formation may be due to the activation of this type of NOS. In addition, $\mathrm{Ba}^{2+}$-activated NOS was blocked by a NO synthesis inhibitor, LNMMA, at the same concentration required for inhibi- 
tion of $\mathrm{Ca}^{2+}$-activated NOS. These results afford evidence that $\mathrm{Ba}^{2+}$ activates an almost identical NOS to that which can be activated by $\mathrm{Ca}^{2+}$.

The effective concentration range for $\mathrm{Ba}^{2+}$ was 250 times higher than that for $\mathrm{Ca}^{2+}$. The maximal activation by $\mathrm{Ba}^{2+}$ was $50-70 \%$ of the maximal activation by $\mathrm{Ca}^{2+}$. This may be due to the different affinities of these cations for calmodulin, which is known to play a crucial role in the activation of NOS (1). Previous studies have shown that $\mathrm{Ba}^{2+}$, which had a lower affinity for calmodulin (12), was less effective than $\mathrm{Ca}^{2+}$ in eliciting phosphodiesterase activity (12) and phosphorylation of myosin light chain kinase (13). In the present study, the activation of NOS depended completely on the presense of calmodulin and was abolished by the calmodulin inhibitor calmidazolium. Therefore, the affinity of these divalent cations for calmodulin could markedly affect their NOS activation capabilities.

Our results do not directly address the issue of whether the extracellular $\mathrm{Ba}^{2+}$ concentration, $2.5 \mathrm{mM}$, used in the previous study $(10)$ is sufficient to activate intracellular NOS during the stimulation of NMDA receptors. The correlation of a known extracellular concentration with the eventual intracellular one does not appear to be the same between $\mathrm{Ca}^{2+}$ and $\mathrm{Ba}^{2-}$, because they are taken up into intracellular stores or removed to the extracellular spaces in different ways. The differences in handling these cations have been discussed in previous studies concerning the calmodulin-dependent contraction of smooth muscle (13) and $\mathrm{Ca}^{2+}$-ATPase in human erythrocytes (14). In these experiments $\mathrm{Ba}^{2+}$ was shown to accumulate readily inside cells. To determine any quantitative relationship between the required concentration of $\mathrm{Ba}^{2+}$ to affect NOS activity and the extracellular concentration required for the physiological response, further studies of the accumulation of $\mathrm{Ba}^{2+}$ inside NOS-containing cells are needed. Although the physiological significance of the $\mathrm{Ba}^{2+}$-induced NOS activation is yet unknown, the present results, at least in part, explain some interesting phenomena: the $\mathrm{Ba}^{2+}$-induced increase in cGMP in rat cerebellum (10) and the $\mathrm{Ba}^{2+}$-induced endothelium-dependent relaxation in canine coronary arteries (8).

In conclusion, $\mathrm{Ba}^{2+}$ can activate cerebellar NOS in a calmodulin-dependent manner. This may lead to an increase in CGMP in the cerebellum stimulated by NMDA in the presense of $\mathrm{Ba}^{2+}$. The present study provides evidence of a possible action of $\mathrm{Ba}^{2+}$ on the calmodulindependent pathway.

\section{Acknowledgment}

This study was supported by a Grant-in-Aid from the Ministry of Education, Science, Sports and Culture, Japan.

\section{REFERENCES}

1 Bredt DS and Snyder SH: Isolation of nitric oxide synthetase, a calmodulin-requiring enzyme. Proc Natl Acad Sci USA 87, $682-685(1990)$

2 Schmidt HHHW, Pollock JS, Nakane M, Gorsky LD, Förstermann U and Murad F: Purification of a soluble isoform of a guanylyl cyclase-activating-factor synthase. Proc Natl Acad Sci USA 88, 365-369 (1991)

3 Garthwaite J, Charles SL and Chess-Williams R: Endotheliumderived relaxing factor release on activation of NMDA receptors suggests role as intercellular messenger in the brain. Nature 336, $385-388$ (1988)

4 Bredt DS and Snyder SH: Nitric oxide mediates glutamatelinked enhancement of CGMP levels in the cerebellum. Proc Natl Acad Sci USA 86, 9030-9033 (1989)

5 Garthwaite J, Garthwaite G, Palmer RMJ and Moncada S: NMDA receptor activation induces nitric oxide synthesis from arginine in rat brain slices. Eur J Pharmacol 172, 413-416 (1989)

6 Kiedrowski L, Costa E and Wroblewski JT: Glutamate receptor agonists stimulate nitric oxide synthase in primary cultures of cerebellar granule cells. J Neurochem 58, 335-341 (1992)

7 Gorbunov $\mathrm{N}$ and Esposito E: Activation of glutamate receptors stimulates the formation of nitrite in synaptosomes from rat cerebellum. J Neurochem 62, 2205-2211 (1994)

8 Yamazaki J, Ohara F, Harada Y and Nagao T: Barium and strontium can substitute for calcium in stimulating nitric oxide production in the endothelium of canine coronary arteries. Jpn J Pharmacol 68, 25-32 (1995)

9 Mayer ML and Westbrook GL: Permeation and block of $N$ methyl-D-aspartic acid receptor channels by divalent cations in mouse cultured central neurons. J Physiol (Lond) 394, 501- 527 (1987)

10 Carter CJ, Noel F and Scatton B: Ionic mechanisms implicated in the stimulation of cerebellar cyclic GMP levels by $N$-methylD-aspartate. J Neurochem 49, 195-200 (1987)

11 Schoenmakers TJM, Visser GJ, Flik G and Theuvenet APR: Chelator: An improved method for computing metal ion concentrations in physiological solutions. Biotechniques 12, $870-879$ (1992)

12 Chao S-H, Suzuki Y Zysk JR and Cheung WY: Activation of calmodulin by various metal cations as a function of ionic radius. Mol Pharmacol 26, 75-82 (1984)

13 Satoh S, Kubota Y, Itoh T and Kuriyama H: Mechanisms of the $\mathrm{Ba}^{2+}$-induced contraction in smooth muscle cells of the rabbit mesenteric artery. J Gen Physiol 89, 215-237 (1987)

14 Graf E, Verma AK, Gorski JP, Lopaschuk G, Niggli V, Zurini M, Carafoli E and Penniston JT: Molecular properties of calcium-pumping ATPase from human erythrocytes. Biochemistry 21, 4511-4516 (1982) 